\title{
Pyrobaculum oguniense sp. nov., a novel facultatively aerobic and hyperthermophilic archaeon growing at up to $97^{\circ} \mathrm{C}$
}

\author{
Yoshihiko Sako, Takuro Nunoura and Aritsune Uchida
}

Author for correspondence: Yoshihiko Sako. Tel: +81 75753 6218. Fax: +81 757536226 . e-mail: sako@kais.kyoto-u.ac.jp

Laboratory of Marine Microbiology, Graduate School of Agriculture, Kyoto University, Kyoto 606-8502, Japan

\begin{abstract}
A novel hyperthermophilic, heterotrophic, rod-shaped archaeon was isolated from a terrestrial hot spring at Oguni-cho, Kumamoto Prefecture, Japan. The new isolate, strain $\mathrm{TE7}^{\top}$, grew under aerobic, microaerobic and anaerobic conditions. Isolate $\mathrm{TE7}^{\mathrm{T}}$ grew optimally at $90-94^{\circ} \mathrm{C}$ and $\mathrm{pH} 7 \cdot 0-7 \cdot 5$ (adjusted at $25^{\circ} \mathrm{C}$ ) under atmospheric air with vigorous shaking. Strain $\mathrm{TE7}^{\top}$ cells were motile rods 2-10 $\mu \mathrm{m}$ in length and covered with a surface-layer lattice. Cell yields at $90^{\circ} \mathrm{C}$ under aerobic conditions were twice that under anaerobic conditions. Under aerobic conditions, growth was inhibited by elemental sulfur, but thiosulfate stimulated growth. Under anaerobic conditions, no growth was observed in the presence of nitrate and nitrite, but elemental sulfur, thiosulfate, L-cystine and oxidized glutathione stimulated growth. The 16S rDNA sequence of TE7 $7^{\top}$ exhibited a close relationship to the sequences of Pyrobaculum aerophilum and Thermoproteus neutrophilus, which belong to the cluster of the genus Pyrobaculum. DNA-DNA hybridization analysis showed a low level of DNA similarity between $\mathrm{TE7}^{\top}$ and previously described Pyrobaculum species. As TE7 is phenotypically and phylogenetically different from the other members of this genus, it is described as a new species named

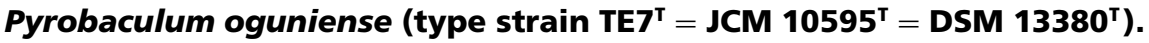

Keywords: Pyrobaculum oguniense sp. nov., facultative aerobe, hyperthermophile, archaeon

\section{INTRODUCTION}

A number of hyperthermophiles, growing above $90{ }^{\circ} \mathrm{C}$, have been isolated from geothermal environments such as hydrothermal vents, terrestrial hot springs and solfataric fields (Stetter, 1996; Huber \& Stetter, 1998). Because oxygen has a low solubility at high temperature and reducing gases are present, many of the organisms in these environments are anaerobes (Stetter, 1996; Huber \& Stetter, 1998; Adams \& Kelly, 1998). In fact, characterized hyperthermophiles mostly consist of obligate anaerobes, a few facultative microaerophiles (e.g. Pyrobaculum aerophilum, Pyrolobus fumarii and Aquifex pyrophilus) (Adams \& Kelly, 1998;

Abbreviations: DAPI, 4',6'-diamidino-2-phenylindole dihydrochloride; ITS, internal transcriptional spacer; RDP, Ribosomal Database Project; Slayer, surface layer.

The DDBJ accession number for the $16 \mathrm{~S}$ rDNA sequence of strain TE7 ${ }^{\top}$ is AB029339.
Blöchl et al., 1997) and one facultative aerophile (Acidianus infernus) (Segerer et al., 1986). In 1996, the first obligately aerobic and neutrophilic hyperthermophile was reported, namely Aeropyrum pernix, which can grow only under atmospheric air (Sako et al., 1996); recent studies have shown that this species possesses biotechnological features of commercial interest (Sako et al., 1997; Nomura et al., 1998; Morii et al., 1999; Chavez Croocker et al., 1999). Moreover, the full genome sequence of $A$. pernix was fully examined (Kawarabayashi et al., 1999). The isolation of $A$. pernix suggested that there are other unidentified hyperthermophiles highly adapted to aerobic conditions above $100{ }^{\circ} \mathrm{C}$, even in reductive hightemperature environments. However, there have been no reports of the isolation of other novel aerobic hyperthermophiles.

In this study, we tried to isolate a second aerobic and neutrophilic hyperthermophile that can grow under atmospheric air: we succeeded in the cultivation and 
isolation of a novel facultatively aerobic, hyperthermophilic archaeon (growing at temperatures up to $97^{\circ} \mathrm{C}$ ) from a slightly alkaliphilic terrestrial hot spring called the Tuetate hot spring in Oguni-cho, Kumamoto Prefecture, Japan. Here, we describe the unique characterization of the new isolate, the first report of a facultatively aerobic and hyperthermophilic archaeon that grows at temperatures above $90{ }^{\circ} \mathrm{C}$ under neutrophilic conditions.

\section{METHODS}

Strains. $P$. aerophilum IM2 ${ }^{\mathrm{T}}$ (JCM $9630^{\mathrm{T}}$, DSM $7523^{\mathrm{T}}$ ), Pyrobaculum organotrophum $\mathrm{H}^{\mathrm{T}}{ }^{\mathrm{T}}$ (JCM 9190 ${ }^{\mathrm{T}}$, DSM $\left.4185^{\mathrm{T}}\right)$, Pyrobaculum islandicum geo ${ }^{\mathrm{T}}\left(\mathrm{JCM} 9189^{\mathrm{T}}\right.$, DSM $4184^{\mathrm{T}}$ ) and Thermoproteus neutrophilus V24Sta ${ }^{\mathrm{T}}$ (JCM $9278^{\mathrm{T}}$, DSM $2338^{\mathrm{T}}$ ) were obtained from Japan Collection of Microorganisms (JCM; Wako, Japan).

Collection of samples. Effluent water samples $\left(97^{\circ} \mathrm{C}, \mathrm{pH} 8\right.$ in situ) were collected from a terrestrial hot spring, namely the Tuetate hot spring, Oguni-cho, Kumamoto Prefecture, Japan. The samples were stored under aerobic conditions at $5^{\circ} \mathrm{C}$.

Isolation and culture conditions. For enrichment, isolation and cultivation, modified Allen's basal medium (Allen, 1959; Brock et al., 1972) supplemented with $0 \cdot 1 \%(\mathrm{w} / \mathrm{v})$ yeast extract (Difco) and $0 \cdot 1 \%(\mathrm{w} / \mathrm{v}) \mathrm{Na}_{2} \mathrm{~S}_{2} \mathrm{O}_{3} \cdot 5 \mathrm{H}_{2} \mathrm{O}$ was used as the standard medium (MS medium). The $\mathrm{pH}$ of this medium was adjusted to $7 \cdot 0-7 \cdot 5$ with $\mathrm{NaOH}$ at $25^{\circ} \mathrm{C}$ before autoclaving. The enrichment was incubated in screw-capped test tubes (Pyrex; $180 \mathrm{~mm} \times 18 \mathrm{~mm}$ ) containing $7 \mathrm{ml}$ of the medium at $88^{\circ} \mathrm{C}$ under aerobic conditions for $2 \mathrm{~d}$. A serial dilution method was employed and repeated several times to obtain pure cultures (Sako et al., 1996).

Aerobic batch cultures were grown in cotton-plugged $300 \mathrm{ml}$ Erlenmeyer flasks containing $100 \mathrm{ml}$ medium in an air-bath rotary shaker (RGS-32.TT; Sanki Seiki) with vigorous rotary shaking (130 r.p.m.). Anaerobic growth conditions were achieved using a technique of Balch et al. (1979). Autoclaved MS medium $(200 \mathrm{ml})$ in a $500 \mathrm{ml}$ glass bottle (Schott Glaswerke) with a butyl rubber plug was reduced by $0.05 \%(\mathrm{w} / \mathrm{v}) \mathrm{Na}_{2} \mathrm{~S} .9 \mathrm{H}_{2} \mathrm{O}$ and pressurized with $\mathrm{N}_{2}(100 \%$, $200 \mathrm{kPa})$. Resazurin $(0 \cdot 0001 \%, \mathrm{w} / \mathrm{v})$ was used as a redox indicator. For microaerobic growth, the gas phase was replaced with $\mathrm{N}_{2}(100 \%, 200 \mathrm{kPa})$ and the $\mathrm{Na}_{2} \mathrm{~S} .9 \mathrm{H}_{2} \mathrm{O}$ solution was omitted. In this medium, resazurin turns red, indicating the presence of $\mathrm{O}_{2}$.

For the determination of the autotrophic growth under anaerobic conditions, modified Allen's basal medium was supplemented with $0 \cdot 1 \%(\mathrm{w} / \mathrm{v}) \mathrm{Na}_{2} \mathrm{~S}_{2} \mathrm{O}_{3} \cdot 5 \mathrm{H}_{2} \mathrm{O}$ or $1 \%$ (w/v) $\mathrm{S}^{0}$, and the gas phase was $\mathrm{H}_{2}: \mathrm{CO}_{2}(80: 20,200 \mathrm{kPa})$ or $\mathrm{N}_{2}: \mathrm{CO}_{2}(80: 20,200 \mathrm{kPa})$. For autotrophic growth under aerobic conditions, only $0 \cdot 1 \%(\mathrm{w} / \mathrm{v}) \mathrm{Na}_{2} \mathrm{~S}_{2} \mathrm{O}_{3} \cdot 5 \mathrm{H}_{2} \mathrm{O}$ was added.

$P$. aerophilum $\mathrm{IM}^{\mathrm{T}}\left(=\mathrm{JCM} 9630^{\mathrm{T}}=\mathrm{DSM} 7523^{\mathrm{T}}\right)$ was grown in BSY medium (Völkl et al., 1993). P. organotrophum $\mathrm{H} 10^{\mathrm{T}}\left(=\mathrm{JCM} 9190^{\mathrm{T}}=\mathrm{DSM} 4185^{\mathrm{T}}\right)$ and $P$. islandicum geo ${ }^{\mathrm{T}}$ $\left(=\mathrm{JCM} 9189^{\mathrm{T}}=\mathrm{DSM} 4184^{\mathrm{T}}\right)$ were grown in JCM 184 medium (JCM Catalogue of Strains, 7th edition, 1999). T. neutrophilus V24Sta ${ }^{\mathrm{T}}$ (= JCM 9278 $=$ DSM 2338 ${ }^{\mathrm{T}}$ ) was grown in JCM 195 medium. Anaerobic culture conditions for P. aerophilum, P. organotrophum and P. islandicum were achieved by using the same methods as those described above. For T. neutrophilus, the gas phase was replaced with $\mathrm{H}_{2}: \mathrm{CO}_{2}(80: 20,200 \mathrm{kPa})$. The cultivation temperature of these organisms was $90^{\circ} \mathrm{C}$.

Light- and electron microscopy. Cells were observed with a differential interference microscope (UFX; Nikon). For observations with transmission electron microscopy, cells were fixed with $2 \%(\mathrm{v} / \mathrm{v})$ glutaraldehyde in $0.1 \mathrm{M}$ $\mathrm{Na}_{2} \mathrm{HPO}_{4} / \mathrm{KH}_{2} \mathrm{PO}_{4}(\mathrm{pH} 7 \cdot 2)$ buffer and post-fixed with $1 \%$ $(\mathrm{v} / \mathrm{v}) \mathrm{OsO}_{4}$. They were then dehydrated with ethanol and embedded in epoxy resin. Ultrathin sections were stained with uranyl acetate and lead acetate and examined under an $\mathrm{H}-700 \mathrm{H}$ electron microscope (Hitachi) at an accelerating voltage of $100 \mathrm{kV}$. Negative staining of cells for electron microscopy was achieved with $2 \%(\mathrm{v} / \mathrm{v})$ phosphotungstic acid.

Determination of growth. Cell densities were determined by direct counting of cells stained with $4^{\prime}, 6^{\prime}$-diamidino-2phenylindole dihydrochloride (DAPI), using an epifluorescence microscope (UFX-IIA; Nikon).

$\mathrm{pH}$ and temperature ranges for growth. The $\mathrm{pH}$ range for growth was determined in MS medium under aerobic conditions with rotary shaking (130 r.p.m.). For the determination of the $\mathrm{pH}$-dependency of growth, the $\mathrm{pH}$ value of the medium was adjusted at $25^{\circ} \mathrm{C}\left(\mathrm{pH}_{25}{ }^{\circ} \mathrm{C}\right)$ with $\mathrm{NaOH}$ and $\mathrm{H}_{2} \mathrm{SO}_{4}$; then the $\mathrm{pH}$ values were also determined at $80{ }^{\circ} \mathrm{C}\left(\mathrm{pH}_{80}{ }^{\circ} \mathrm{C}\right)$. The $\mathrm{pH}_{80}{ }^{\circ} \mathrm{C}$ values of $5 \cdot 4,6 \cdot 1,6 \cdot 3,6 \cdot 6,6 \cdot 8$ and $7 \cdot 4$ corresponded to $\mathrm{pH}_{25}{ }^{\circ} \mathrm{C}$ values of $5 \cdot 5,6 \cdot 5,7 \cdot 0,7 \cdot 5,8 \cdot 0$ and $9 \cdot 0$, respectively. For the determination of the temperature range for growth, the cultures were incubated at different temperatures under aerobic conditions at $\mathrm{pH}_{25{ }^{\circ} \mathrm{C}} 7 \cdot 0$ $\left(\mathrm{pH}_{80}{ }^{\circ} \mathrm{C}=6 \cdot 3\right)$.

Substrate utilization. To determine organic-substrate utilization, each of following substrates (at $0 \cdot 1 \% \mathrm{w} / \mathrm{v}$ unless specified otherwise) was added to modified Allen's basal medium, supplemented with $\mathrm{Na}_{2} \mathrm{~S}_{2} \mathrm{O}_{3} .5 \mathrm{H}_{2} \mathrm{O} \quad(0 \cdot 1 \%)$ $\left(\mathrm{pH}_{25}{ }^{\circ} \mathrm{C}\right.$ adjusted to 7.0): yeast extract, trypticase peptone (BBL), yeast extract $(0.05 \%)$ and trypticase peptone $(0.05 \%)$, gelatin (Sigma), casein (Sigma), casamino acids (Difco), starch (Wako), D-(+)-glucose, sucrose, lactose, maltose, sodium acetate, and sodium pyruvate. To determine sulfur-compound utilization, the MS medium without $\mathrm{Na}_{2} \mathrm{~S}_{2} \mathrm{O}_{3} \cdot 5 \mathrm{H}_{2} \mathrm{O}$, but with the following sulfur compounds, was used: $\mathrm{Na}_{2} \mathrm{SO}_{3}(0 \cdot 1 \%), \mathrm{S}^{0}(1 \%)$, glutathione (the oxidized form) $(0 \cdot 1 \%)$, L-cysteine $\mathrm{HCl}(0 \cdot 1 \%)$, L-cystine $(0 \cdot 1 \%)$. For the determination of nitrate respiration, $\mathrm{NaNO}_{2}$ $(0 \cdot 1 \%)$ and $\mathrm{NaNO}_{3}(0 \cdot 1 \%)$ were added to the MS medium prepared under anaerobic conditions.

Antibiotic resistance. The antibiotic resistance of the isolate was tested using chloramphenicol (Sigma), penicillin G (Sigma), rifampicin (Sigma), streptomycin (Sigma) and vancomycin (Nacalai Tesque). All of the antibiotics were tested individually at a concentration of $100 \mu \mathrm{g} / \mathrm{ml}$ in the MS medium. Cells were grown overnight at $80^{\circ} \mathrm{C}$ in either the presence or the absence of the antibiotic under aerobic conditions. The resistance of Pyrobaculum species to these antibiotics at $80^{\circ} \mathrm{C}$ was determined previously by Huber et al. (1987) and Völkl et al. (1993).

Detection of $\mathrm{H}_{2} \mathrm{~S}$ as a metabolic product. $\mathrm{H}_{2} \mathrm{~S}$ was detected qualitatively using the technique described by Huber et al. (1998).

DNA isolation and base composition. DNA was isolated as described by Lauerer et al. (1986). The $\mathrm{G}+\mathrm{C}$ content $(\mathrm{mol} \%)$ of the genomic DNA was determined using HPLC 
(Tamaoka \& Komagata, 1984) with a DNA-GC kit (Yamasa Shouyu).

$16 \mathrm{~S}$ rDNA analysis. The 16S rDNA was amplified by the PCR. The primers employed in the amplification had the sequences 5'-TTC CGG TTG ATC CYG CCG GA (21F) and 5'-ACG GNT ACC TTG TTA CGA CTT (1492R), which correspond to positions 7-26 and 1512-1492, respectively, in the 16S rDNA (Escherichia coli numbering; DeLong, 1992). The PCR product was directly cloned into the pCRII vector (Invitrogen) and sequenced by the deoxynucleotide chain-termination method, using an ABI 373A automated DNA sequencer (Applied Biosystems). The 16S rDNA sequence was aligned with a subset of 16S rDNA sequences obtained from the DNA Database of Japan (DDBJ) and the Ribosomal Database Project (RDP) by using the ODEN software package (version 1.1, National Institute of Genetics, Mishima, Japan). Neighbour-joining analysis (Saitou \& Nei, 1987) of 1371 bases of sequence from each organism was accomplished using the ODEN software package.

DNA-DNA hybridization. DNA from strain $\mathrm{TE7}^{\mathrm{T}}$ was compared with DNA from $P$. aerophilum IM2 ${ }^{\mathrm{T}}\left(=\mathrm{JCM} 9630^{\mathrm{T}}\right.$ $\left.=\operatorname{DSM} 7523^{\mathrm{T}}\right)$, P. organotrophum $\mathrm{H} 10^{\mathrm{T}}\left(=\mathrm{JCM} 9190^{\mathrm{T}}=\right.$ DSM $\left.4185^{\mathrm{T}}\right), P$. islandicum geo3 ${ }^{\mathrm{T}}\left(=\mathrm{JCM} 9189^{\mathrm{T}}=\mathrm{DSM}\right.$ $\left.4184^{\mathrm{T}}\right)$ and T. neutrophilus $\mathrm{V} 24 \mathrm{Sta}^{\mathrm{T}}\left(=\mathrm{JCM} 9278^{\mathrm{T}}=\mathrm{DSM}\right.$ $2338^{\mathrm{T}}$ ) by using the fluorometric DNA-DNA hybridization method, with photobiotion-labelled DNA as described by Ezaki et al. (1989).

Confirmation of strain purity. DNA was isolated from both aerobic and anaerobic culture. The 16S rDNA and the internal transcriptional spacer (ITS) region between the 16S rDNA and the 23S rDNA were amplified by the PCR. The primers employed in the amplification had the sequences $5^{\prime}$ CGGTTGGATCACCTC (1528F) and 5'-GTTGGTTTCTTTTCCT (0213aR) in the 16S rDNA and 23S rDNA, respectively (Achenbach \& Woese, 1995). The PCR product was directly cloned into the pCRII vector. All $1016 \mathrm{~S}$ rDNA clones from both aerobic and anaerobic cultures of TE7 ${ }^{\mathrm{T}}$ were analysed using RFLP. All 10 ITS region clones from both aerobic and anaerobic cultures of TE ${ }^{\mathrm{T}}$ were sequenced by using the deoxynucleotide chain-termination method, using an ABI 373A automated DNA sequencer (Applied Biosystems).

\section{RESULTS}

\section{Enrichment and isolation}

Enrichment of effluent water samples was carried out in MS medium at $88{ }^{\circ} \mathrm{C}$. A single population of rodshaped cells was observed after $2 \mathrm{~d}$ incubation. Only rod cells were observed, i.e. no coccoid, branched or variantly rod-shaped cells were seen. A culture of rodshaped cells was purified by serial dilution, and strain TE7 $^{\mathrm{T}}$ ( = JCM $10595^{\mathrm{T}}$ ) was isolated. The purity of this strain was routinely confirmed by microscopic examination. Furthermore, RFLP analysis of the $16 \mathrm{~S} \mathrm{rDNA}$ gene fragment of 10 PCR-amplified clones (data not shown) as well as sequencing analysis of the ITS region between the 16S rDNA and 23S rDNA gene of 10 additional PCR-amplified clones from both aerobic and anaerobic cultures (data not shown) were examined to confirm the purity of the strain.

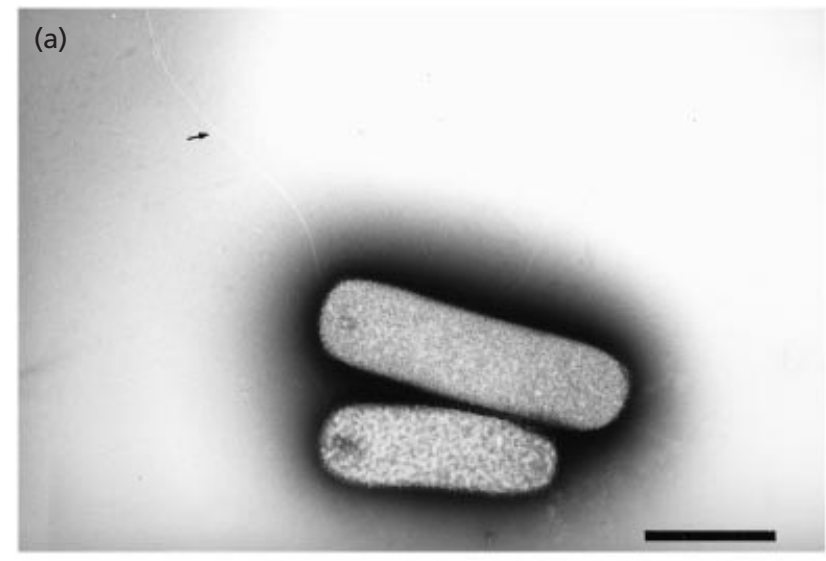

(b)
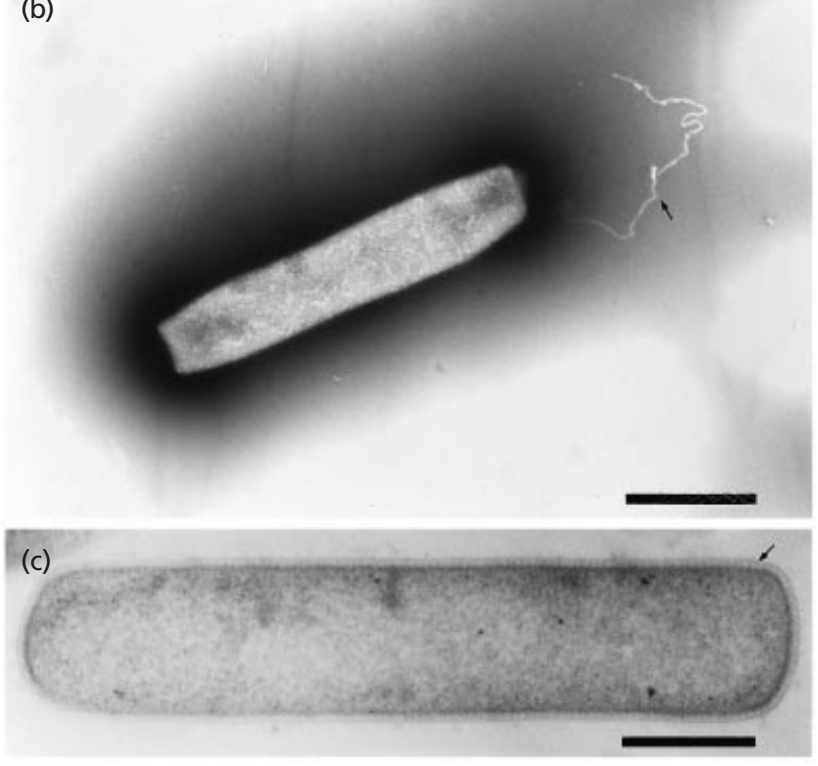

Fig. 1. Transmission electron micrographs of cells of Pyrobaculum oguniense TE ${ }^{\top}$. (a) Negatively stained cells at exponential growth phase. An arrow indicates the flagellum. Bar, $1 \mu \mathrm{m}$. (b) Negatively stained cell at stationary phase. An arrow indicates the pilus-like structure. Bar, $1 \mu \mathrm{m}$. (c) Ultrathin section of a whole cell of strain TE7 ${ }^{\top}$. Arrow indicates the surface layer (S-layer). Bar, 0.5 $\mu \mathrm{m}$.

\section{Morphology}

Cells of isolate TE $7^{\mathrm{T}}$ were rod-shaped, with a width of $0 \cdot 6-1 \cdot 0 \mu \mathrm{m}$ and a length of $2-10 \mu \mathrm{m}$ (Fig. 1a-c). Golfclub-like cells were observed only in the stationary growth phase of an aerobic culture grown in a test tube. These cells were found at the bottom of the test tube in a zone that was reduced by the growth of cells. However, branched cells were never observed. Motility was observed, using a differential interference microscope, even at stationary phase. Whilst monopolar flagellation is present in the exponential phase (Fig. 1a), flagella are absent in the stationary phase, and a thick pilus-like structure (Zillig et al., 1983) is observed (Fig. 1b). Negatively stained and thin-section micrographs showed that the cell wall consisted of typical 

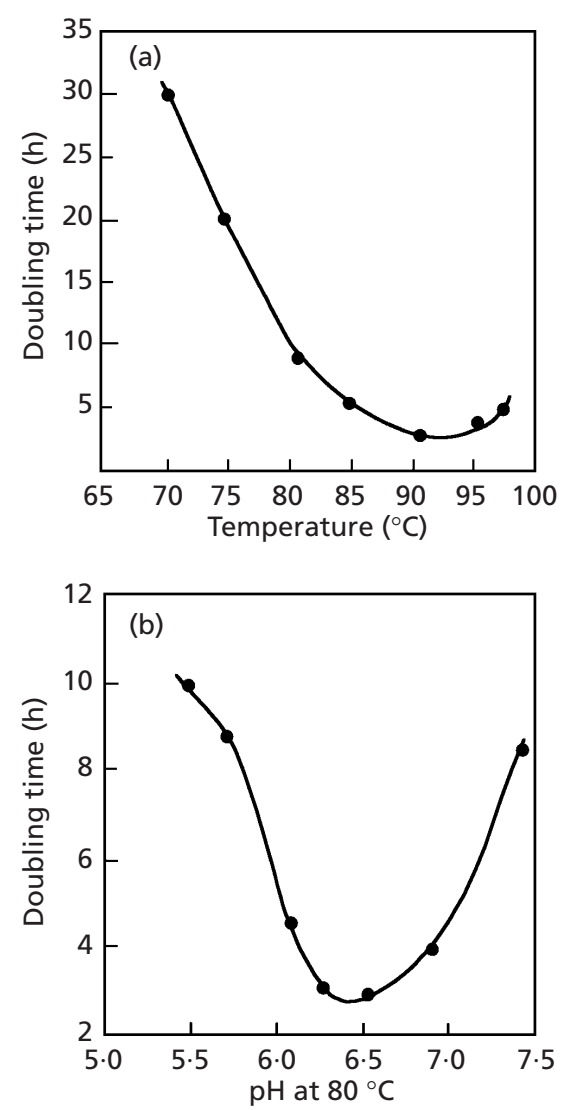

Fig. 2. Effect of temperature (a) and $\mathrm{pH}$ at $80^{\circ} \mathrm{C}(\mathrm{b})$ on the growth of $P$. oguniense TE7 ${ }^{\top}$.

surface-layer (S-layer) protein (Fig. 1a-c). Cells appeared singly or formed X- or V-shaped aggregates of a few cells after growth in the MS medium. Aggregates with diameters of up to $1 \mathrm{~mm}$ were found after growth with trypticase peptone as the substrate.

\section{Effects of temperature, $\mathrm{pH}$ and salt concentration on growth}

TE $7^{\mathrm{T}}$ grew over a temperature range of $70-97^{\circ} \mathrm{C}$, with an optimum at $90-94^{\circ} \mathrm{C}$ (Fig. 2a). Growth was not observed at $\geqslant 100{ }^{\circ} \mathrm{C}$ or at $\leqslant 60^{\circ} \mathrm{C}$. Growth of isolate $\mathrm{TE7}^{\mathrm{T}}$ occurred between $\mathrm{pH}_{80}{ }^{\circ} \mathrm{C} 5.4$ and 7.4 with an optimum of $\mathrm{pH}_{80}{ }^{\circ} \mathrm{C} 6 \cdot 3-7 \cdot 0$. No growth was observed at $\mathrm{pH}_{80}{ }^{\circ} \mathrm{C} 5.0$ and $\mathrm{pH}_{80}{ }^{\circ} \mathrm{C} 7 \cdot 6$ (Fig. 2b). $\mathrm{TE}^{\mathrm{T}}$ did not require $\mathrm{NaCl}$ for growth and grew in the presence of $0-1.5 \%(\mathrm{w} / \mathrm{v}) \mathrm{NaCl}$. The optimal concentration for growth was $0 \% \mathrm{NaCl}$. No growth was observed above $2 \%(\mathrm{w} / \mathrm{v}) \mathrm{NaCl}$ (data not shown). There was no difference between aerobic and anaerobic culture in terms of these growth requirements.

\section{Physiological characterization of growth}

Under optimal conditions, the doubling time was $3-4 \mathrm{~h}$ in aerobic culture and $6 \mathrm{~h}$ in microaerobic and anaerobic culture. New isolate $\mathrm{TE7}^{\mathrm{T}}$ could grow heterotrophically on proteinaceous complex substrates such as $0 \cdot 1 \%(\mathrm{w} / \mathrm{v})$ yeast extract or $0.05 \%(\mathrm{w} / \mathrm{v})$ yeast extract and $0.05 \%(\mathrm{w} / \mathrm{v})$ trypticase peptone in the absence of sulfur compounds under aerobic conditions. However, in the presence of $\mathrm{Na}_{2} \mathrm{~S}_{2} \mathrm{O}_{3} .5 \mathrm{H}_{2} \mathrm{O}$, the growth yield of $\mathrm{TE}^{\mathrm{T}}$ increased fourfold and the

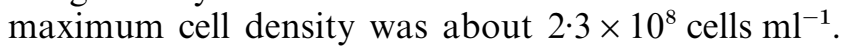
With trypticase peptone as the sole substrate, a cell density of $1 \cdot 0 \times 10^{8}$ cells $\mathrm{ml}^{-1}$ was obtained. No growth was observed with casein, gelatin, casamino acids, starch, D-(+)-glucose, sucrose, lactose, maltose, sodium acetate or sodium pyruvate as the sole carbon source. $\mathrm{Na}_{2} \mathrm{SO}_{3}(0 \cdot 1 \%)$ and $\mathrm{S}^{0}(1 \%)$ inhibited aerobic growth. $\mathrm{H}_{2} \mathrm{~S}$ was not formed under aerobic conditions.

Under microaerobic and anaerobic conditions, TE $7^{\mathrm{T}}$ grew heterotrophically and required sulfur compounds. The maximum cell density under both conditions reached from $5.6 \times 10^{7}$ to $6.0 \times$ $10^{7}$ cells $\mathrm{ml}^{-1}$ with $0 \cdot 1 \%(\mathrm{w} / \mathrm{v})$ yeast extract in the presence of $\mathrm{Na}_{2} \mathrm{~S}_{2} \mathrm{O}_{3} .5 \mathrm{H}_{2} \mathrm{O}$. Furthermore, growth was observed on $0.05 \%(\mathrm{w} / \mathrm{v})$ yeast extract and $0.05 \%$ $(\mathrm{w} / \mathrm{v})$ trypticase peptone, with a cell density of about $3.5 \times 10^{7}$ cells $\mathrm{ml}^{-1}$. Very weak growth was observed on trypticase peptone, gelatin, casamino acids and acetate, with cell densities of about $5 \times 10^{6}$ cells ml ${ }^{-1}$. $\mathrm{S}^{0}$, glutathione (the oxidized form), L-cystine and $\mathrm{Na}_{2} \mathrm{~S}$ could replace $\mathrm{Na}_{2} \mathrm{~S}_{2} \mathrm{O}_{3} .5 \mathrm{H}_{2} \mathrm{O}$, supporting a cell yield of $3.5 \times 10^{7}$ to $4.5 \times 10^{7}$ cells ml ${ }^{-1}$. L-Cysteine could also support growth. However, the cell yield was only $6.5 \times 10^{6}$ cells $\mathrm{ml}^{-1} . \mathrm{H}_{2} \mathrm{~S}$ was detected following growth with these sulfur compounds (data not shown). These results suggested that these sulfur compounds may be used as electron acceptors. No growth was observed in MS medium under anaerobic conditions in the presence of $\mathrm{NaNO}_{2}$ or $\mathrm{NaNO}_{3}$ (data not shown). Autotrophic growth was not observed under either aerobic or anaerobic conditions.

\section{Antibiotic resistance}

Isolate $\mathrm{TE} 7^{\mathrm{T}}$ was resistant to streptomycin and vancomycin and sensitive to rifampicin, like other Pyrobaculum spp. However, growth was slightly inhibited by chloramphenicol and penicillin G. In contrast, other Pyrobaculum spp. are insensitive to these antibiotics (Huber et al., 1987; Völkl et al., 1993).

\section{DNA base composition}

The $\mathrm{G}+\mathrm{C}$ content of isolate $\mathrm{TE7}^{\mathrm{T}}$ was $48 \mathrm{~mol} \%$, as determined by HPLC analysis.

\section{$16 \mathrm{~S}$ rDNA gene sequence analysis}

The size of the PCR products of 16S rDNA was 2269 nucleotides, which consists of 1472 nucleotides of exons and two introns. One intron (INT Pog-IV) is $32 \mathrm{bp}$ long (1173-1204; numbers are relative to the beginning of this PCR product) and the other intron (INT Pog-V) is $665 \mathrm{bp}$ long (1213-1877). The $16 \mathrm{~S}$ rDNA sequence of isolate $\mathrm{TE}^{\mathrm{T}}$ was very similar to 


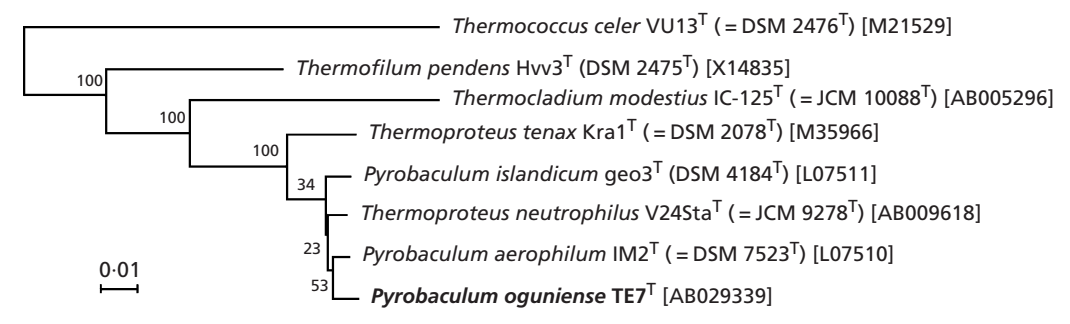

Fig. 3. Phylogenetic tree of crenarchaeotes within the Thermoproteales inferred from $16 \mathrm{~S}$ rDNA sequences by using the neighbour-joining method on 1371 bases of sequence from each organism. Each number indicates the bootstrap value from 100 trials. Bar, 1 substitution per 100 nucleotides. The GenBank accession numbers are in square brackets.

Table 1 DNA-DNA hybridization between Pyrobaculum oguniense strain TE7 ${ }^{\top}$, other Pyrobaculum species and Thermoproteus neutrophilus

-, Not determined.

\begin{tabular}{|c|c|c|c|c|c|}
\hline \multirow[t]{2}{*}{ Source of microplate-bound DNA } & \multicolumn{5}{|c|}{ Source of photobiotin-labelled DNA } \\
\hline & Strain $\mathrm{TE7}^{\mathrm{T}}$ & P. aerophilum & P. islandicum & P. organotrophum & T. neutrophilus \\
\hline P. oguniense TE7 ${ }^{\mathrm{T}}$ & 100 & 5 & 2 & 2 & 5 \\
\hline P. aerophilum $\mathrm{IM}^{\mathrm{T}}$ & 15 & 100 & 7 & 1 & - \\
\hline$P$. islandicum geo $3^{\mathrm{T}}$ & 3 & 3 & 100 & 77 & - \\
\hline P. organotrophum $\mathrm{H}_{1} 0^{\mathrm{T}}$ & 4 & 4 & 72 & 100 & - \\
\hline T. neutrophilus $\mathrm{V} 24 \mathrm{Sta}^{\mathrm{T}}$ & 4 & - & - & - & 100 \\
\hline
\end{tabular}

those of members of the Thermoproteaceae. The closest sequences were from $P$. aerophilum ( $99 \cdot 1 \%$ similarity), T. neutrophilus $(98.9 \%$ similarity) and $P$. islandicum (98.5\% similarity). Lower similarity $(96.9 \%)$ was found with Thermoproteus tenax. Fig. 3 shows the phylogenetic relationship between isolate $\mathrm{TE}^{\mathrm{T}}$ and other members of the Thermoproteales.

\section{DNA-DNA hybridization}

The DNA of isolate TE7 ${ }^{\mathrm{T}}$ yielded a very low hybridization signal with the isolated DNA of $P$. aerophilum, $P$. islandicum, $P$. organotrophum and $T$. neutrophilus. Even the strongest hybridization signals with $P$. aerophilum were under $20 \%$ (Table 1 ).

\section{DISCUSSION}

New isolate $\mathrm{TE7}^{\mathrm{T}}$ was a rod-shaped, facultative aerobic, heterotrophic and hyperthermophilic archaeon growing optimally at a temperature above $90{ }^{\circ} \mathrm{C}$. The phylogenetic analysis of $16 \mathrm{~S}$ rDNA sequences showed that for isolate $\mathrm{TE}^{\mathrm{T}}$ the closest known species were $P$. aerophilum and $T$. neutrophilus. The type species of the genus Pyrobaculum is $P$. islandicum, which was included in the same cluster of $P$. aerophilum and T. neutrophilus. On the other hand, the type species of the genus Thermoproteus is T. tenax (Zillig et al., 1981), which was less closely related. Moreover, bootstrap analysis consistently placed $T$. tenax outside the cluster of Pyrobaculum spp. The classification of $T$. neutrophilus and recently isolated Pyrobaculum spp. was not dependent on the phylogeny of 16S rDNA analysis (Fischer et al., 1983; Huber et al., 1987). In terms of physiology, T. tenax is a acidophile (Zillig et al., 1981), but Pyrobaculum spp. and T. neutrophilus are neutrophiles (Fischer et al., 1983; Huber et al., 1987; Völkl et al., 1993). In view of these facts, isolate $\mathrm{TE}^{\mathrm{T}}$ should be a member of the genus Pyrobaculum (Fig. 3) and T. neutrophilus should be reclassified within the genus Pyrobaculum. Whilst the isolate $\mathrm{TE7}^{\mathrm{T}}, P$. aerophilum and T. neutrophilus were closely related in $16 \mathrm{~S}$ rDNA sequence analyses, the DNA-DNA hybridization analysis showed very low similarities in genomic DNA (Table 1), and the $\mathrm{G}+\mathrm{C}$ content of TE7 ${ }^{\mathrm{T}}(48 \mathrm{~mol} \%)$ is lower than that of $P$. aerophilum (52 mol\%) (Völkl et al., 1993) and $T$. neutrophilus $(60 \mathrm{~mol} \%)$ (Itoh et al., 1998). Thus, TE7 ${ }^{\mathrm{T}}$, $P$. aerophilum and $T$. neutrophilus clearly represent distinct species in the genetic analysis.

Isolate $\mathrm{TE} 7^{\mathrm{T}}$ has unique features of respiration. Under aerobic conditions, growth of $\mathrm{TE} 7^{\mathrm{T}}$ appeared to be particularly dependent on aerobic respiration, which was inhibited by $\mathrm{S}^{0}$ and $\mathrm{Na}_{2} \mathrm{SO}_{3}$. This phenomenon has been observed in P. aerophilum (Völkl et al., 1993). However, $P$. aerophilum grows in microaerobic conditions $(0.5-1.0 \%$ oxygen $)$ but not in aerobic conditions with vigorous shaking under atmospheric air. Under anaerobic conditions, growth of $\mathrm{TE}^{\mathrm{T}}$ depends on sulfur compounds such as $\mathrm{Na}_{2} \mathrm{~S}_{2} \mathrm{O}_{3}, \mathrm{~S}^{0}$, glutathione (the oxidized form) and L-cystine, and it produces $\mathrm{H}_{2} \mathrm{~S}$. These growth characteristics are similar to those of $P$. islandicum and P. organotrophum (Huber et al., 1987) under anaerobic conditions. Alternatively, nitrate reduction, which in $P$. aerophilum depends on anaerobic conditions (Völkl et al., 1993), was not observed. Thus, it can be said that $\mathrm{TE} 7^{\mathrm{T}}$ has a chimeric- 
type respiration, i.e. $P$. aerophilum-type respiration under aerobic conditions and $P$. islandicum-type respiration under anaerobic conditions. Furthermore, $T$. neutrophilus and $P$. islandicum grow autotrophically in the presence of $\mathrm{H}_{2}$ and $\mathrm{S}^{0}$ (Fischer et al., 1983; Schäfer et al., 1986; Huber et al., 1987), and P. aerophilum grows autotrophically by the oxidation of $\mathrm{H}_{2}$ or thiosulfate (Völkl et al., 1993), whereas autotrophic growth of $\mathrm{TE}^{\mathrm{T}}$ was not observed.

In addition, the growth of TE7 ${ }^{\mathrm{T}}$ was slightly inhibited by chloramphenicol and penicillin $\mathrm{G}$, which could not inhibit the growth of other Pyrobaculum species (Huber et al., 1987; Völkl et al., 1993). Also, TE ${ }^{\mathrm{T}}$ was not capable of growing above $0.5 \% \mathrm{NaCl}$, whereas the optimum $\mathrm{NaCl}$ concentration for growth of $P$. aerophilum is $1.5 \% \mathrm{NaCl}$ (Völkl et al., 1993). Furthermore, the maximum growth temperature of other Pyrobaculum species is over $100^{\circ} \mathrm{C}$ (Fischer et al., 1983; Huber et al., 1987; Völkl et al., 1993). In contrast, TE $7^{\mathrm{T}}$ could not grow above $97^{\circ} \mathrm{C}$. The optimum $\mathrm{pH}$ for $\mathrm{TE}^{\mathrm{T}}$ is $\mathrm{pH} 7$, but that for $P$. islandicum and $P$. organotrophum is $\mathrm{pH} 6$ (Huber et al., 1987). Therefore, on the basis of the genomic DNA comparison and the physiological properties, we propose that $\mathrm{TE}^{\mathrm{T}}$ represents a new species of Pyrobaculum, which we have named Pyrobaculum oguniense (named after the isolation locale, Oguni-cho). The type strain is isolate TE7 ${ }^{\mathrm{T}}$.

The close phylogenetic relationship between $P$. aerophilum and $P$. oguniense is the first example of a relationship between a microaerophile and an aerophile in the deepest and short branches within the phylogenetic tree. Aerobic metabolic pathways have been suggested to be a modern adaptation in the history of respiration (Dickerson et al., 1976; Broda \& Peschek, 1979). The phylogenetic analysis of cytochrome oxidase indicates that the aerobic metabolism had a single origin and was present in the last common ancestor of all organisms (Castresana et al., 1994, 1995; Castresana \& Saraste, 1995; Castresana \& Moreira, 1999). In addition, geochemical analysis indicates that traces of oxygen could already have been formed photochemically early in the history of the Earth (Towe, 1990). Therefore, molecular and biochemical comparison of $P$. aerophilum and $P$. oguniense may show the nature of the development of aerobic respiration and the systems for oxidative stress in ancient types of organisms. On the other hand, the differences in anaerobic respiration between $P$. aerophilum and $P$. oguniense are also interesting. Recent molecular analysis has suggested that the last common ancestor of living organisms might have also possessed nitrate, sulfate and sulfur respiration (Castresana \& Moreira, 1999). In addition, $P$. aerophilum contains the gene for proteins of the enzymic machinery of sulfate and sulfur respiration (Fitz-Gibbon et al., 1997), even though these physiological activities have not been detected. These facts suggest that the genus Pyrobaculum still possesses the respiratory ability possessed by the common ancestor of living organisms for billion of years and that they may choose the most appropriate respiration system for their habitat. Therefore, the molecular and biochemical investigation of respiration of $P$. oguniense may provide insights into survival strategies in such extreme environments.

\section{Description of Pyrobaculum oguniense $\mathrm{TEZ}^{\top}$ sp. nov.}

Pyrobaculum oguniense (o.gu.ni.en'se. M. L. neut. adj. oguniense pertaining to Oguni-cho, which is the town of the Tuetate hot spring).

The cells are rod-shaped and usually between 2 and $10 \mu \mathrm{m}$ long and between 0.6 and $1.0 \mu \mathrm{m}$ wide. Motile by monopolar flagellation. Cell wall composed of protein surface layer. Growth between 70 and $97^{\circ} \mathrm{C}$ (optimum, $90-94{ }^{\circ} \mathrm{C}$ ), at $\mathrm{pH}_{80}{ }^{\circ} \mathrm{C} 5.4$ and 7.4 (optimum $\left.\mathrm{pH}_{80}{ }^{\circ} \mathrm{C} 6 \cdot 3-7 \cdot 0\right)$ and up to $1.5 \% \mathrm{NaCl}(\mathrm{w} / \mathrm{v}$ ) (optimal at $0 \%$ ). Optimal doubling time of $180 \mathrm{~min}$ under aerobic conditions and $360 \mathrm{~min}$ under anaerobic and microaerobic conditions. Heterotrophic growth with yeast extract and trypticase peptone. Sulfur inhibits aerobic growth but stimulates anaerobic growth. Oxygen, thiosulfate, sulfur, L-cystine and glutathione (oxidized form) are possible electron acceptors. The $\mathrm{G}+\mathrm{C}$ content of genomic DNA is about $48 \mathrm{~mol} \%$. $16 \mathrm{~S}$ rDNA sequence exhibits $99 \cdot 1-98 \cdot 5 \%$ similarity to those of Pyrobaculum aerophilum, Thermoproteus neutrophilus and Pyrobaculum islandicum. Isolate obtained from water samples of a terrestrial hot spring (Tuetate hot spring), Oguni-cho, Kumamoto Prefecture, Japan. The type strain is Pyrobaculum oguniense TE$^{\mathrm{T}}\left(=\mathrm{JCM} 10595^{\mathrm{T}}=\mathrm{DSM} 13380^{\mathrm{T}}\right)$.

\section{ACKNOWLEDGEMENTS}

We would like to thank Dr Ken Takai, Japan Marine Science and Technology Centre (JAMSTEC), Yokosuka, Japan, for his advice and suggestions. We are grateful to $\mathrm{Mr}$ Takahiko Higasa, Research Institute of Food Science, Kyoto University, Japan, for the electron micrographs.

\section{REFERENCES}

Adams, M. W. W. \& Kelly, R. M. (1998). Finding and using hyperthermophilic enzymes. Trends Biotechnol 16, 329-332.

Allen, M. B. (1959). Studies with Cyanidium caldarium, an anomalously pigmented chlorophyte. Arch Microbiol 32, 270-277.

Archenbach, L. \& Woese, C. (1995). 16S and 23S rRNA-like primers. In Archaea: a Laboratory Manual, vol. 3, Thermophiles, pp. 201-203. Edited by F. T. Robb \& A. R. Place. Cold Spring Harbor, NY: Cold Spring Harbor Laboratory.

Balch, W. E., Fox, G. E., Magrum, L. J., Woese, R. C. \& Wolfe, R. S. (1979). Methanogens: re-evaluation of a unique biological group. Microbiol Rev 43, 260-296.

Blöchl, E., Rachel, R., Burggraf, S., Jannasch, H. W. \& Stetter, K. (1997). Pyrolobus fumarii, gen. and sp. nov., represents a novel group of archaea, extending the upper temperature limit for life to $113^{\circ} \mathrm{C}$. Extremophiles 1, 14-21.

Brock, T. D., Brock, M. B., Belly, R. T. \& Weiss, R. L. (1972). Sulfolobus: a new genus of sulfur-oxidizing bacteria living at low pH and high temperature. Arch Microbiol 84, 54-68. 
Broda, E. \& Peschek, G. A. (1979). Did respiration or photosynthesis come first? J Theor Biol 81, 201-212.

Castresana, J. \& Moreira, D. (1999). Respiratory chains in the last common ancestor of living organisms. J Mol Evol 49, 453-460.

Castresana, J. \& Saraste, M. (1995). Evolution of energetic metabolism: the respiration-early hypothesis. Trends Biochem Sci 20, 443-448.

Castresana, J., Lübben, M., Saraste, M. \& Higgins, D. G. (1994). Evolution of cytochrome oxidase, an enzyme older than atmospheric oxygen. EMBO J 13, 2516-2525.

Castresana, J., Lübben, M. \& Saraste, M. (1995). New archaebacterial genes coding for redox proteins: implications for the evolution of aerobic metabolism. J Mol Biol 250, 202-210.

Chavez Crooker, P., Sako, Y. \& Uchida, A. (1999). Purification and characterization of intracellular heat-stable proteinase (pernilase) from the marine hyperthermophilic archaeon Aeropyrum pernix K1. Extremophiles 3, 3-9.

DeLong, E. F. (1992). Archaea in coastal marine environments. Proc Natl Acad Sci US A 89, 5685-5689.

Dickerson, R. E., Tomkovich, R. \& Almassy, R. J. (1976). The cytochrome fold and the evolution of bacterial energy metabolism. J Mol Biol 100, 473-491.

Ezaki, T., Hashimoto, Y. \& Yabuuchi, E. (1989). Fluorometric deoxyribonucleic acid-deoxyribonucleic acid hybridization in microdilution wells as an alternative to membrane filter hybridization in which radioisotopes are used to determine genetic relatedness among bacterial strains. Int J Syst Bacteriol 39, 224-229.

Fischer, F., Zillig, W., Stetter, K. O. \& Schreiber, G. (1983). Chemolithoautotrophic metabolism of anaerobic extremely thermophilic archaebacteria. Nature 301, 511-513.

Fitz-Gibbon, S., Choi, A. J., Miller, J. H., Stetter, K. O., Simon, M. I., Swanson, R. \& Kim, U.-J. (1997). A fosmid-based genomic map and identification of 474 genes of the hyperthermophilic archaeon Pyrobaculum aerophilum. Extremophiles 1, 36-51.

Huber, H. \& Stetter, K. O. (1998). Hyperthermophiles and their potential in biotechnology. J Biotechnol 64, 39-52.

Huber, R., Kristjansson, J. K. \& Stetter, K. O. (1987). Pyrobaculum gen. nov., a new genus of neutrophilic, rod-shaped archaebacteria from continental solfataras growing optimally at $100{ }^{\circ} \mathrm{C}$. Arch Microbiol 149, 95-101.

Huber, R., Dyba, D., Huber, H., Burggraf, S. \& Rachel, R. (1998). Sulfur-inhibited Thermosphaera aggregans sp. nov., a new genus of hyperthermophilic archaea isolated after its prediction from environmentally derived $16 \mathrm{~S}$ rRNA sequences. Int $J$ Syst Bacteriol 48, 31-38.

Itoh, T., Suzuki, K. \& Nakase, T. (1998). Occurrence of introns in the 16S rRNA genes of members of the genus Thermoproteus. Arch Microbiol 170, 155-161.

Kawarabayashi, Y., Hino, Y., Horikawa, H. \& 27 other authors (1999). Complete genome sequence of an aerobic hyperthermophilic crenarchaeon, Aeropyrum pernix K1. DNA Res 6 , 83-101.
Lauerer, G., Kristjansson, J. K., Langworthy, T. A., König, H. \& Stetter, K. O. (1986). Methanothermus sociabilis sp. nov., a second species within the Methanothermaceae growing at $97^{\circ} \mathrm{C}$. Syst Appl Microbiol 8, 100-105.

Morii, H., Yagi, H., Akutsu, H., Nomura, N., Sako, Y. \& Koga, Y. (1999). A novel phosphoglycolipid archaetidyl (glucosyl) inositol with two sesterterpanyl chains from the aerobic hyperthermophilic archaeon Aeropyrum pernix K1. Biochem Biophys Acta 1436, 426-436.

Nomura, N., Sako, Y. \& Uchida, A. (1998). Molecular characterization and postsplicing fate of three introns within the single rRNA operon of the hyperthermophilic archaeon Aeropyrum pernix K1. J Bacteriol 180, 3635-3643.

Saitou, N. \& Nei, M. (1987). The neighbor-joining method: a new method for reconstructing phylogenetic trees. Mol Biol Evol 4, 406-425.

Sako, Y., Nomura, N., Uchida, A., Ishida, Y., Morii, H., Koga, Y., Hoaki, T. \& Maruyama, T. (1996). Aeropyrum pernix gen. nov., sp. nov., a novel aerobic hyperthermophilic archaeon growing at temperatures up to $100^{\circ} \mathrm{C}$. Int J Syst Bacteriol 46, 1070-1077.

Sako, Y., Croocker, P. C. \& Ishida, Y. (1997). An extremely heatstable extracellular proteinase (aeropyrolysin) from the hyperthermophilic archaeon Aeropyrum pernix K1. FEBS Lett 415, 329-334.

Schäfer, S., Barkowski, C. \& Fuchs, G. (1986). Carbon assimilation by the autotrophic thermophilic archaebacterium Thermoproteus neutrophilus. Arch Microbiol 146, 301-308.

Segerer, A., Neuner, A., Kristjansson, J. K. \& Stetter, K. O. (1986). Acidianus infernus gen. nov., sp. nov., and Acidianus brierleyi comb. nov.: facultatively aerobic, extremely acidophilic thermophilic sulfur-metabolizing archaebacteria. Int $J$ Syst Bacteriol 36, 559-564.

Stetter, K. O. (1996). Hyperthermophilic prokaryotes. FEMS Microbiol Rev 18, 149-158.

Tamaoka, J. \& Komagata, K. (1984). Determination of DNA base composition by reversed-phase high-performance liquid chromatography. FEMS Microbiol Lett 25, 125-128.

Towe, K. M. (1990). Aerobic respiration in the Archaean? Nature 348, 54-56.

Völkl, P., Huber, R., Drobner, E., Rachel, R., Burggraf, S., Trincone, A. \& Stetter, K. O. (1993). Pyrobaculum aerophilum sp. nov., a novel nitrate-reducing hyperthermophilic archaeum. Appl Environ Microbiol 59, 2918-2926.

Zillig, W., Stetter, K. O., Schäfer, W., Janekovic, D., Wunderl, S., Holz, I. \& Palm, P. (1981). Thermoproteales: a novel type of extremely thermoacidophilic anaerobic archaebacteria isolated from Icelandic solfataras. Zentbl Bakteriol Hyg 1 Abt Orig C 2, 205-227.

Zillig, W., Gierl, A., Schreiber, G., Wunderl, S., Janekovic, D., Stetter, K. O. \& Klenk, H. P. (1983). The archaebacterium Thermofilum pendens represents a novel genus of the thermophilic, anaerobic sulfur respiring Thermoproteales. Syst Appl Microbiol 4, 79-87. 